\title{
Urinary stone characteristics of patients treated with extracorporeal shock wave lithotripsy in Cipto Mangunkusumo Hospital Jakarta, 2008-2014: a gender analysis
}

\author{
Endrika Noviandrini, Ponco Birowo, Nur Rasyid \\ Department of Urology, Faculty of Medicine, Universitas Indonesia, Cipto Mangunkusumo Hospital, Jakarta, Indonesia
}

\begin{abstract}
ABSTRAK
Latar belakang: Pasien dengan batu saluran kemih di Indonesia terus meningkat setiap tahunnya di kedua gender. Data menunjukkan insiden penyakit batu saluran kemih umumnya di temukan lebih tinggi pada pria dibandingkan wanita. Tujuan dari penelitian ini untuk mengetahui karakteristik dari Pasien dengan batu saluran kemih, baik pria maupun wanita yang menjalani extracorporeal shock wave lithotripsy (ESWL) di Rumah Sakit Cipto Mangunkusumo (RSCM), Jakarta tahun 2008-2014.
\end{abstract}

Metode: Penelitian ini menggunakan data dari rekam medis pasien ESWL tahun 2008-2014 di RSCM Jakarta. Kami mengambil 5.174 dari 6.020 data, dikarenakan ketidaklengkapan status. Data kemudian di sortir berdasarkan jenis kelamin, usia, lokasi batu, opasitas batu, ukuran batu, riwayat ESWL pada pasien dan dianalisis menggunakan SPSS v.20 untuk Mac.

Hasil: Dari 5.174 data, didapatkan insiden Pasien dengan batu saluran kemih pada pria dua kali lebih besar dibanding wanita $(66,3 \%: 33,6 \%)$ dan terjadi pada usia produktif $(65,2 \%$ pria dan $65.9 \%$ wanita). Batu ginjal unilateral menjadi batu yang paling banyak ditemukan di kedua gender (50,2\% pria dan 57,2\% wanita) dengan lokasi yang terbanyak yaitu kaliks inferior $(24,8 \%$ pria dan $28,9 \%$ wanita). Sebanyak $72,9 \%$ merupakan batu radioopak (73,7\% pria dan $71,5 \%$ wanita). Rerata ukuran panjang batu pada pasien pria dan wanita adalah $11,34 \pm 7,15 \mathrm{~mm}$ dan $11,90 \pm 7,54 \mathrm{~mm}$, secara berurutan. Penelitian ini juga menunjukkan bahwa 79,3\% pasien datang untuk terapi ESWL pertama.

Kesimpulan: Batu saluran kemih ditemukan dua kali lebih tinggi pada pria dibandingkan wanita dan terjadi pada usia produktif. Batu ginjal unilateral yang berlokasi di kaliks inferior menjadi batu yang paling banyak di temukan di kedua gender. Sebagian besar batu merupakan batu radio opak.

ABSTRACT

Background: The incidence of urinary stone patient in Indonesia has increased every year in both genders. Data showed that urolithiasis was higher in male rather than female. The aimed of this study was to describe the characteristics of urinary stone found in patient who underwent extracorporeal shock wave lithotripsy (ESWL) at Cipto Mangunkusumo Hospital, Jakarta from 2008-2014.

Methods: Data obtained from ESWL medical record Cipto Mangunkusumo Hospital, Jakarta from 2008-2014. We obtained 5,174 out of 6,020 data due to incompleteness data record. We sorted data records by gender, age, stone location, stone opacity, size of the stone, and history of ESWL, and analyzed by statistic tools (SPSS v 20 for Mac).

Results: From 5,174 records, we found that the incidence of urinary stones was two times higher in male rather than female $(66.3 \%: 33.64 \%)$, occurred mostly in productive age (65.2\% male, $65.9 \%$ female). Unilateral kidney stone was most common location found for both gender $(50.2 \%$ male, $57.2 \%$ female), and most frequent site located in calyx inferior (24.8\% male, $28.9 \%$ female). About $72.9 \%$ stone was radiopaque $(73.7 \%$ male and $71.5 \%$ female). The mean size of the stone in male and female was $11.34 \pm 7.15 \mathrm{~mm}$ and $11.90 \pm 7.54 \mathrm{~mm}$, respectively. This study also showed that 79.3\% patients came for first ESWL.

Conclusion: Urinary stone founds two times higher in male than female, and mostly occurs on their productive ages. Unilateral kidney stone in calyx inferior become the most common stone found in both gender. Most of the stone has radiopaque opacity.

Keywords: ESWL, female, male, urinary stone, urolithiasis

pISSN: 0853-1773 • eISSN: 2252-8083 • http://dx.doi.org/10.13181/mji.v24i4.1258• Med J Indones. 2015;24:234-8 - Received 25 Jun $2015 \cdot$ Accepted 30 Dec 2015

Correspondence author: Endrika Noviandrini, dr.endrika@gmail.com

Copyright @ 2015 Authors. This is an open access article distributed under the terms of the Creative Commons Attribution-NonCommercial 4.0 International License (http://creativecommons.org/licenses/by-nc/4.0/), which permits unrestricted non-commercial use, distribution, and reproduction in any medium, provided the original author and source are properly cited. 
Urinary stone disease has become one of the most common urologic diseases found in Indonesia. In Cipto Mangunkusumo Hospital (CMH), the numbers of urinary stone incidences has been increased every year. During 1997-2002, the numbers of patients who underwent extracorporeal shock wave lithotripsy (ESWL) was increased five times than before. ${ }^{1}$ Research shows that urinary stone disease occurs mostly in man, rather than woman. And it usually happens in their productive ages. ${ }^{1}$

There are some procedures that can be used as the treatment of urinary stone disease. One of the most common procedures used among urologist is ESWL. ESWL not only known as the non-invasive procedures, but also for its good in stone free rate outcomes. $^{2}$ The successful rate of ESWL as the treatment of all urinary tract stone was $96 \%{ }^{3}$ Another supporting research showed, about $87 \%$ stone free rate was achieved after three months follow up in urethral stone treatment by using ESWL and no major complications found. ${ }^{4}$

The aimed of this study was to describe the urinary stone characteristic in male and female patient who underwent ESWL at CMH, Jakarta, during 2008-2014.

\section{METHODS}

This research used secondary data taken from medical record of urinary stone patient who treated with ESWL at CMH, Jakarta from 2008-2014. There were 6,020 patients who underwent ESWL during those specific years, only 5,174 with complete medical records included in this research. The inclusion criteria of this research were female and male patient who had urolithiasis and underwent ESWL during 2008-2014, in Cipto Mangunkusumo Hospital, Jakarta. We exclude patients with incomplete data, and patients with CBD stone. The variables were age, gender, and location of stone, stone site, stone opacity, stone size, and history of ESWL. We divided the stone location into unilateral kidney stone, bilateral kidney stone, unilateral urethral stone, bilateral urethral stone and bladder stone. The stone site consisted of calyx inferior stone, calyx media stone, calyx superior stone, distal urethral stone, proximal urethral stone, and bladder stone. We also classified patient age into three categories: under 19 years old, 20-50 years old, and more than 51 years old. This criteria of age was made based on literature which stated that the highest incidences of urolithiasis was in patient around 20-50 years old. ${ }^{5}$ Confidentiality of subjects identity were guaranteed.

After collecting the data, we sorted it by gender, and analyzed it with SPSS v.20 for Mac. The frequency distribution of stone characteristic in both gender and the mean size of the stone were analyzed by using this statistic tools.

\section{RESULTS}

Table 1 describes the urinary stone characteristics in patients related with gender. Urinary stone found mostly in male in their productive ages. Unilateral kidney stone, which located in the calyx inferior of the kidney was mostly found with radioopacity.

Table 1. Characteristic of urinary stone

\begin{tabular}{lcc}
\hline & $\begin{array}{c}\text { Male } \\
\mathrm{n}=3,433\end{array}$ & $\begin{array}{c}\text { Female } \\
\mathrm{n}=1,741\end{array}$ \\
\hline Age & & \\
$\quad \leq 19$ years old & 38 & 43 \\
\hline 20-50 years old & 2,241 & 1,147 \\
\hline 251 years old & 1,154 & 551 \\
\hline Stone & & \\
\hline Unilateral kidney stone & 1,722 & 995 \\
\hline Bilateral kidney stone & 202 & 126 \\
\hline Unilateral uretheral stone & 1,337 & 484 \\
\hline Bilateral uretheral stone & 108 & 124 \\
\hline Bladder stone & 64 & 12 \\
\hline Site of stone & & \\
\hline Calyx inferior & 852 & 503 \\
\hline Calyx media & 416 & 226 \\
\hline Calyx superior & 277 & 129 \\
\hline Pyelum & 379 & 263 \\
\hline Ureter distal & 766 & 335 \\
\hline Ureter Proximal & 679 & 273 \\
\hline Bladder & 64 & 12 \\
\hline Opacity & & \\
\hline Radiopaque & 2,532 & 1,244 \\
\hline Radiolucent & 901 & 497 \\
\hline Mean size of the stone (mm) & $11.34 \pm 7.15$ & $11.90 \pm 7.54$ \\
\hline First time ESWL & & \\
\hline Nos & 2,777 & 1,327 \\
\hline & 656 & \\
\hline
\end{tabular}

*ESWL=extracorporeal shock wave lithotripsy 


\section{DISCUSSION}

There are many contributing factors for the risk of stone formation such as race, environment, gender, and age. ${ }^{2}$ Distribution of stone varies among races. Renal stones are more common in Caucasians and Asians than Native Americans and Afro Caribbeans. ${ }^{6}$ Incidences of urinary stone disease was higher in hot or dry climates. ${ }^{7}$

Gender is also related to the incidence of urinary tract stone. Our study results showed that the prevalence of urinary tract stone in Indonesia was higher in male rather than female, with the ratio 2:1. This finding was also supported by literature, which stated that urinary tract stone occurs mostly in male ${ }^{5}$. The same study has been done in Israel, China, and Taiwan for the past five years and came up with the similar result.-9 In the other hand, a research conducted in Florida on 2010 found that nowadays the incidence of stone disease among woman might be increased. There is a changing pattern in urinary tract stone prevalence. Female also has the same risk of getting urinary tract stone like male. ${ }^{10}$

Anatomy of the urinary tract, obesity, dietary life, urine composition, and hormonal factors may be considered as the factors which can explaine why the incidences of urinary stone was higher in male. Male urinary tract has more narrow places than female. This narrow places are lead to the higher risk of stone formation due to urine precipitation. ${ }^{11}$ The most common locations for urinary stone formation are ureteropelvic junctions, mid ureter (ureter crosses over iliac bone), ureter crosses over the iliac blood vessels, ureter bladder junction, and when the ureter under the uterine artery passes (for female). ${ }^{5}$

Obesity, dietary life, and fluid consumption also play some role in stone formation process. Studies in United States in 2011 found that obese females were more likely to develop stones than non-obese females. But the correlation between obesity and stones was weaker in males rather than the female..$^{12}$ Negri et $\mathrm{al}^{13}$ also found that in female with high body mass index (BMI) tend to have an increasing number of oxalate, uric acid, phosphorus, creatinine, and sodium excretion. The same result found in male subject but potassium, urea, magnesium, and citrate excretion was also increased in this gender. ${ }^{13}$ Eating habit, like high animal protein consumption, low carbohydrate, high salt, and low calcium dietary habits, may contribute to the stone formation process in male. ${ }^{5}$ Eating vegetable and fiber, and limit animal protein consumption to $0.8-1.0 \mathrm{~g} / \mathrm{kg} /$ day are recommended to inhibit stone formation. ${ }^{14}$ Fluid intake also related to the risk of kidney stone formation ${ }^{15}$. It was suggested in the guidelines to drink 2.5-3.0 L/day or to drink until the amount of diuresis reached 2.0-2.5 L/day, to prevent the stone recurrences. Beverages with neutral $\mathrm{pH}$ is recommend for this prevention tips. ${ }^{14}$ Coffee, tea, alcohol, and milk may decreased urinary concentration. ${ }^{16}$

Urine composition is related to calculogenesis process in human. A study about biochemical composition of urine was conducted in India, by using two hours urine collection. The result of that study found that male had higher risk in getting urinary stone due to higher excretion of calcium and oxalate, with low concentrations of citrate. $^{17}$

Sex hormones also have some role in stone formation process. Estrogen inhibits excretion of calcium and oxalate, and increase citrate production. ${ }^{18}$ Study done by Sarada et al ${ }^{17}$ reported that testosterone decreased citrate excretion. Another study in animal also showed oxalate excretion was increased by the administration of testosteron. ${ }^{17}$ In addition protective effect of estrogen in premenopausal woman, could enhanced renal calcium absorption and reduced bone resorption. ${ }^{15}$

This might also explained why age was related with stone formation process. In this study, found that the highest incidence age of urinary stone, was between 20-50 years old. This result also supported by literature which stated that the highest incidence of urinary stone usually found in the fourth to sixth decades of life. And in female patients, the second peak reached during the menopausal era. ${ }^{15}$ Loss of estrogen effect and increased of calcium excretion in postmenopausal woman may explained this condition. ${ }^{17}$ The reason why urinary stone disease mostly found in productive ages still remains uncertain. However, social economic differences, cultures, and dietary life considered as the explanation. ${ }^{19}$ 
In this study, unilateral kidney stone which located in the calyx inferior, was the most common stone found in both gender. The correlation between location and stone formation remain uncertain, but narrow places in human urinary tract increased the risk of urine precipitation..$^{5}$ The incidence of bladder stone found higher in male because in elderly male, bladder stone might develop due to the growth of the prostate or due to benign prostatic hyperplasia. ${ }^{11}$

The data result also showed that most of the stone found in both gender was radioopaque, which usually related to calcium oxalate, calcium phosphate and struvite stones. Calcium oxalate stone found about $60 \%$ in all types of calculi stones. ${ }^{6}$ Study by Gault and Chafe $^{20}$ stated that in the third decade, the highest number type of stone found in female was phosphate stone and oxalate stone in male.

The mean size of the stone found in the study was $11.34 \pm 7.15 \mathrm{~mm}$ for male patients and $11.90 \pm 7.54$ $\mathrm{mm}$ for female patients. ESWL found to be the most suitable treatment for this size of stone. ${ }^{21}$ From the guidelines ESWL is the first treatment chosen for kidney stone with size $10-20 \mathrm{~mm} .{ }^{22}$

There are many factors which correlate with successful rate of ESWL such as size, composition, consistency of the stone and elimination process after the treatment. ${ }^{23}$ In this research, most of the patients came for the first treatment $(80.8 \%$ in male and $76.2 \%$ in female), but some patients had already done it before. This might be due to the size and the composition of the stone. But, further information about stone composition and stone hounsfield unit are needed. Recent studies have shown that stone made of calcium oxalate dihydrate are easier to break rather than uric acid stone. $^{3}$ Studies made by Tarawneh stated that there were positive correlation between stone size and number of ESWL treatment. ${ }^{23}$ This study result also showed, that the number of male patients who come for continued treatment was higher than female patients. This result may be correlate with literature which stated that the recurrences of urinary stone occurs higher in male rather than female. ${ }^{5}$

The weakness of this study was incomplete data records which was found especially on the year of 2008. We solved this problem by increasing the quality of medical record documentation with the result of better medical record during 2009-2014.

In conclusion, this research showed that in $\mathrm{CMH}$, Jakarta, from 2008-2014, most of the patients who had urinary tract stone and underwent ESWL were male. The most common location found in both gender was unilateral kidney stone with calyx inferior as the specific site. Most of the patients had radioopaque imaging and calcium oxalate stone considered as the highest type of stone found in this study.

\section{Conflict of interest}

The authors affirm no conflict of interest in this study.

\section{REFERENCES}

1. Rahardjo D, Hamid R. Perkembangan penatalaksanaan batu ginjal di RSCM tahun 1997-2002. J I Bedah Indones. 2004;32(2):58-63. Indonesian.

2. Politis G, Griffith DP. ESWL: stone-free efficacy based upon stone size and location. World J Urol. 1987;5:255-8.

3. Junuzovic D, Prstojevic JK, Hasanbegovic M, Lepara Z. Evaluation of extracorporeal shock wave lithotripsy (ESWL): efficacy in treatment of urinary system stones. Acta Inform Med. 2014;22(5):309-14.

4. Elkholy MM, Ismail H, Abdelkhalek MA, Badr MM, Elfeky MM. Efficacy of extracorporeal shockwave lithotripsy using Dornier SII in different levels of ureteral stones. Urol Ann. 2014;6(4):346-51.

5. Menon M.Parulkar BG, Drach GW. Urinary lithiasis: etiology, diagnosis, and medical management. In: Walsh CP, Retik AB, Vaughan ED, Wein AJ, editors. Campbell's urology. 7th ed. Philadelphia: WB Saunders; 1998. p. 2662-5.

6. Pal RP, Mellon JK. Renal Stone Disease. Foundation Years. 2008;4(5):199-203.

7. Kalbu DU, Golan S, Livne PM, Pode D, Duvdevani M, Lifshitz D. Urinary stone composition in Israel: current status and variation with age and gender-A bicenter study. J Endourol. 2013;27(12):1539-42.

8. Wu W, Yang B, Ou L, Liang Y, Wan S, Li S, et al. Urinary stone analysis on 12,846 patients: a report from a single center in China. Urolithiasis. 2014;42(1):39-43.

9. Huang WY, Chen YF, Carter S, Chang HC, Lan CF, Huang KH. Epidemiology of upper urinary tract stone disease in a Taiwanese population: a nationwide, population based study. J Urol. 2013;189(6):2158-63. 
10. Strope SA, Wolf JS Jr, Hollenbeck BK. Changes in gender distribution of urinary stone disease. Urology. 2010;75(3):543-6.

11. Burnett AL, Rodriguez R, Jarrett TW. Genitourinary system: male anatomy and physiologi. In: Greenfield LJ, Mulholland MW, Oldham KT, Zelenock GB, Lilimoe KD, editors. Essentials of Surgery Scientific Principles and Practice. 2nd ed. New York: Lippincott Williams \& Wilkins; 1997. p.1111-8.

12. Nowfar S, Pallazi-Churas K, Chang DC, Sur RL. The relationship of obesity and gender prevalence changes in United States inpatient nephrolithiasis. Urology. 2011;78(5):1029-33.

13. Negri AL, Spivacow FR, Del Valle EE, Forrester M, Rosende G, Pinduli I. Role of overweight and obesity on the urinary excretion of promoters and inhibitors of stone formation in stone formers. Urol Res. 2008;36(6):303-7.

14. Skolarikos A, Straub M, Knoll T, Sarica K, Seitz C, Petřík $A$, et al. Metabolic evaluation and recurrence prevention for urinary stone patients: EAU guidelines. Eur Urol. 2015;67(4):750-63.

15. Pearle MS, Lotan Y. Urinary lithiasis: etiology, epidemiology, and pathogenesis. In: Wein AJ, Kavoussi LR, editors. Campbell-Walsh Urology. Philadelphia: Elsevier Saunders; 2012. p.1257-60.

16. Taylor EN, Curhan GC. Diet and fluid prescription in stone disease. Kidney Int. 2006;70(5):835-9.
17. Sarada B, Satyanarayana U. Urinary composition in men and women and the risk of urolithiasis. Clin Biochem. 1991;24(6):487-90.

18. Kato Y, Yamaguchi S, Kakizaki H, Yachiku S. Influence of estrus status on urinary chemical parameters related to urolithiasis. Urol Res. 2005;33(6):476-80.

19. Eprints.undip.ac.id [Internet]. Semarang: Batu saluran kemih suatu problema gaya hidup dan pola makan serta analisis ekonomi pada pengobatannya. [update 2007 Mar 3; cited 2015 Jun 15]. Available from: http://eprints.undip.ac.id/340/1/rifki_ muslim.pdf

20. Gault MH, Chafe L. Relationship of frequency, age, sex, stone weight and composition in 15,624 stones: comparison of results for 1980 to 1983 and 1995 to 1998. J Urol. 2000;164(2):302-7.

21. Renner C, Rassweiler J. Treatment of renal stones by extracorporeal shock wave lithotripsy. Nephron. 1999;81(suppl1):71-81.

22. Türk C, Knoll T, Petrik A, Sarica K, Seitz C, Straub M. Indication for active stone removal and selections of procedures. In: EAU Guidelines on Urolithiasis. 2014. p. 48. Available from: http://uroweb.org/wp-content/ uploads/20-Urolithiasis.pdf

23. Tarawneh E, Awad Z, Hani A, Haroun AA, Hadidy A, Mahafza W, et al. Factors affecting urinary calculi treatment by extracorporeal shock wave lithotripsy. Saudi J Kidney Dis Transpl. 2010 Jul; 21(4):660-5. 